\title{
SISTEM PAKAR PEMILIHAN MENU MAKANAN BERDASARKAN PENYAKIT DAN GOLONGAN DARAH
}

\author{
Rina Julita \\ Universitas Dehasen Bengkulu \\ rinajj72@gmail.com
}

\begin{abstract}
Pengaruh golongan darah terhadap program diet sangatlah besar karena dianggap bisa mempengaruhi sistem pencernaan, metabolisme tubuh menurun dan penyakit. Jenis golongan darah yang berbeda juga akan memberikan respon yang berbeda terhadap satu jenis makanan tertentu. Oleh karena itu, penting untuk mengetahui menu makanan apa saja yang bermanfaat dan baik dikonsumsi serta makanan yang sebaiknya dihindari yang sesuai dengan golongan darah. Tujuan penelitian ini adalah membuat sistem pakar untuk menentukan makanan diet vegetarian berdasarkan golongan darah menggunakan metode Backward Chaining. Penelitian dilakukan di Puskesmas Sawah lebar Baru Kota Bengkulu pada Bulan Agustus 2016. Hasil penelitian menunjukkan bahwa dengan adanya Sistem Pakar dengan metode Backward Chaining ini dapat membantu menentukan menu makanan berdasarkan penyakit dan golongan darah.

Kata Kunci: Backward Chaining, Sistem Pakar, Penyakit, Golongan Darah
\end{abstract}

The influence of blood type on diet program is very big because it can affect the digestive system, decreased body metabolism and disease. Different types of blood type will also respond differently to one particular type of food. Therefore, it is important to know what menu is useful and well consumed and should be avoided in accordance with the blood type. The purpose of this research is to create an expert system to determine the diet based on the blood type of a vegetarian diet using Backward Chaining method. The research was conducted at Puskesmas Sawah Lebar Baru, Kota Bengkulu in August 2016. The results showed the expert system with Backward Chaining method can help determining the menu based on disease and blood type.

Keywords: Backward Chaining, Expert System, Disease, Blood Type

\section{PENDAHULUAN}

Saat ini komputer merupakan perangkat yang sangat membantu pekerjaan manusia. Hampir semua bidang memanfaatkan komputer untuk menyelesaikan pekerjaan manusia. Begitu pula halnya dalam dunia medis dengan teknologi berbasis pengetahuan, fakta dan penalaran yang dapat digunakan untuk menyelesaikan berbagai masalah dalam berbagai disiplin ilmu [1]

Pusat Kesehatan Masyarakat (Puskesmas) adalah suatu unit pelaksana fungsional yang berfungsi sebagai pusat kesehatan termasuk di dalamnya melayani kesehatan masyarakat pada suatu wilayah tertentu. Puskesmas Sawah Lebar Baru aktivitas hariannya adalah memberikan pelayanan kesehatan kepada masyarakat akan tetapi sangat disayangkan belum begitu maksimal dalam pemberian layanan kesehatan kepada masyarakat karena puskesmas Sawah Lebar Baru tenaga medisnya masih kurang terutama untuk ahli gizi.

Dari permasalahan di atas, maka dengan itu penulis tertarik untuk mengangkat judul "Sistem Pakar Pemilihan Menu Makanan Berdasarkan Penyakit dan Golongan Darah”. 


\section{LANDASAN TEORI}

\section{A. Konsep Sistem Pakar}

Pada dasarnya Sistem Pakar adalah sistem informasi yang berisi dengan pengetahuan dari pakar sehingga dapat digunakan untuk konsultasi. Pengetahuan dari pakar di dalam sistem ini digunakan sebagi dasar oleh Sistem Pakar untuk menjawab pertanyaan (konsultasi). Kepakaran (expertise) adalah pengetahuan yang ekstensif dan spesifik yang diperoleh melalui rangkaian pelatihan, membaca, dan pengalaman. Pengetahuan membuat pakar dapat mengambil keputusan secara lebih baik dan lebih cepat daripada non-pakar dalam memecahkan problem yang kompleks. Kepakaran mempunyai sifat berjenjang, pakar top memiliki pengetahuan lebih banyak daripada pakar yunior. Tujuan Sistem Pakar adalah untuk mentransfer kepakaran dari seorang pakar ke komputer, kemudian ke orang lain (yang bukan pakar).

\section{Pengertian Sistem Pakar}

Sistem Pakar merupakan sistem yang berusaha mengadopsi pengetahuan manusia ke komputer yang dirancang untuk memodelkan kemampuan menyelesaikan masalah seperti layaknya seorang pakar. Dengan Sistem Pakar ini, orang awam pun dapat menyelesaikan masalahnya atau hanya sekedar mencari suatu informasi berkualitas yang sebenarnya hanya dapat diperoleh dengan bantuan para ahli di bidangnya. Sistem Pakar ini juga akan dapat membantu aktivitas para pakar sebagai asisten yang berpengalaman dan mempunyai asisten yang berpengalaman dan mempunyai pengetahuan yang dibutuhkan. dalam penyusunannya, Sistem Pakar mengkombinasikan kaidah-kaidah penarikan kesimpulan (inference rules) dengan basis pengetahuan tertentu yang diberikan oleh satu atau lebih pakar dalam bidang tertentu. Kombinasi dari kedua hal tersebut disimpan dalam komputer, yang selanjutnya digunakan dalam proses pengambilan keputusan untuk penyelesaian masalah tertentu.

\section{Komponen Sistem Pakar}

Empat komponen pembentuk sistem pakar [1] :

a. Basis Pengetahuan (Knowledge Base)

Basis pengetahuan itu merupakan inti dari program Sistem Pakar dimana basis pengetahuan ini merupakan representasi (Knowledge Representasion) dari seorang pakar.

\section{b. Basis Data (Data Base)}

Basis data adalah bagian yang mencatat semua fakta-fakta, baik fakta awal pada saat sistem mulai beroperasi maupun fakta-fakta yang didapat pada saat proses inferensi sedang berlangsung.

\section{c. Mesin Inferensi (Inferensi Engineer)}

Mesin inferensi adalah bagian yang mengandung mekanisme fungsi berpikir dan pola pola penalaran sistem yang digunakan oleh seorang pakar.

d. Antar Muka Pemakai (User Interface)

Antar muka pemakai adalah bagian penghubung antara program Sistem Pakar dengan pemakai. Antar muka pemakai merupakan bagian software yang menyediakan sarana untuk user agar bisa berkomunikasi dengan sistem.

\section{B. Backward Chaining}

Backward Chaining dimulai dengan daftar tujuan (atau hipotesis) dan bekerja mundur dari konsekuen untuk melihat apakah ada data yang tersedia yang akan mendukung setiap konsekuen ini. Sebuah mesin inferensi menggunakan Backward Chaining akan mencari aturan inferensi sampai menemukan satu yang memiliki konsekuensi (Kemudian klausa) yang cocok dengan tujuan yang diinginkan. Jika yg (jika klausa) dari aturan yang tidak diketahui benar, 
Jurnal Pseudocode, Volume V Nomor 1, Februari 2018, ISSN 2355-5920

www.ejournal.unib.ac.id/index.php/pseudocode

maka itu akan ditambahkan ke daftar tujuan (agar tujuan seseorang untuk dikukuhkan satu juga harus memberikan data yang menegaskan aturan baru ini) [2].

Sering hal ini memerlukan perumusan dan pengujian hipotesis sementara. Pada metode inferensi dengan Backward Chaining akan mencari aturan atau rule yang memiliki konsekuen (Then klausa ..) yang mengarah kepada tujuan yang di skenariokan / di inginkan.

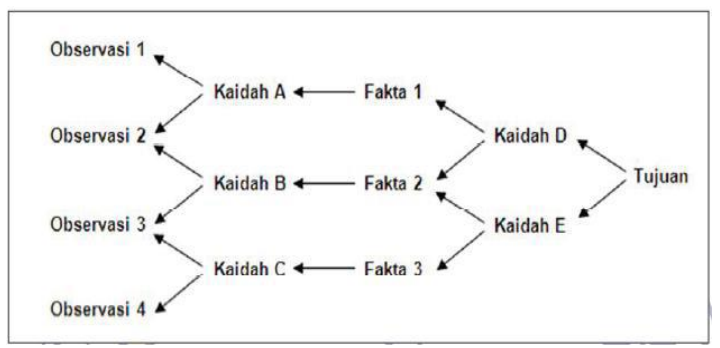

Gambar 1. Rule Backward Chaining

\section{Pemilihan Menu Makanan}

Pemilihan adalah proses, cara, perbutan memilih. Menu adalah susunan makanan atau hidangan yang dimakan oleh seseorang untuk sekali makan atau untuk sehari menurut waktu makan.

Adapun zat-zat yang dibutuhkan oleh tubuh:

a. Energi dibutuhkan oleh tubuh yang berasal dari zat gizi yang merupakan sumber utama, yaitu karbohidrat, lemak, dan protein. Energi yang diperlukan tubuh ini dinyatakan dalam satuan kalori. Widyakarya nasional Pangan dan Gizi VI (WKNPG VI) tahun 1998 menganjurkan angka kecukupan gizi (AKG) energi untuk remaja dan dewasa muda perempuan 2000 2200 kkal, sedangkan untuk laki-laki antara 2400 - 2800 kkal setiap hari.

b. Karbohidrat sebagai zat gizi merupakan nama kelompok zat-zat organik yang mempunyai struktur molekul yang berbeda- beda walaupun terdapat persamaanpersamaan dari sudut kimia dan fungsinya.

c. Lemak disebut juga lipit, adalah suatu zat yang kaya akan energi, berfungsi sebagai sumber energi yang utama untuk proses metabolisme tubuh. Berdasarkan bentuknya lemak digolongkan ke dalam lemak padat.

d. Protein adalah bagian dari semua sel hidup dan merupakan bagian terbesar tubuh sesudah air.

\section{Definisi Penderita Obesitas}

Menurut Kamus Besar Bahasa Indonesia Penderita adalah orang yang menderita (kesusahan, sakit, cacat, dan sebagainya). Obesitas disebabkan oleh ketidakseimbangan antara konsumsi kalori dan kebutuhan energi, di mana konsumsi terlalu berlebih dibandingkan dengan kebutuhan/ pemakaian energi (energy expenditure).

\section{METODOLOGI PENELITIAN}

Pada bab ini akan dijabarkan tentang metode yang digunakan dalam penelitian yang tercakup dalam kerangka kerja penelitian mulai dari mengidentifikasi masalah, menganalisa masalah, mempelajari literatur, menentukan tujuan, pengumpulan data, analisa Backward Chaining, perancangan Sistem Pakar hingga pembuatan prototype system. Tahap-tahap ini dibuat agar penelitian lebih terarah serta mampu mencapai tujuan dalam penelitian ini.

Proses penelitian ini akan dijelaskan dalam suatu kerangka kerja penelitian yang nantinya akan digunakan untuk mengambarkan langkah-langkah dalam penelitian. Adapun kerangka penelitian dijelaskan dengan gambar berikut. 
Jurnal Pseudocode, Volume V Nomor 1, Februari 2018, ISSN 2355-5920 www.ejournal.unib.ac.id/index.php/pseudocode

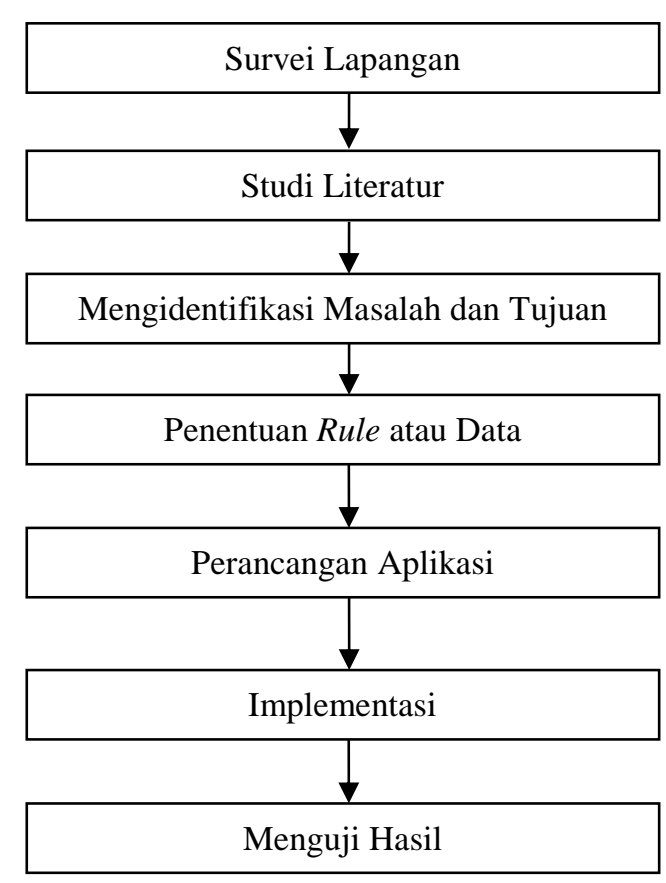

Gambar 2. Kerangka Kerja

\section{ANALISA DAN PERANCANGAN}

\section{A. Pendahuluan}

Sistem Pakar dalam penelitian ini digunakan untuk membantu dalam menentukan menu makanan berdasarkan penyakit dan golongan darah. Analisa sistem berguna untuk mengetahui kebutuhan perangkat lunak yang akan dibangun. Dalam tahap ini dilakukan pengumpulan data serta pengetahuan yang diperlukan untuk mambangun Sistem Pakar, sehingga pada akhirnya hasil dari analisis yang diperoleh berupa sebuah sistem yang strukturnya dapat diidentifikasikan dengan baik dan jelas.

\section{B. Analisa Sistem}

Sistem yang digunakan untuk menentukan menu makanan berdasarkan penyakit dan golongan darah adalah dengan cara memasukkan nama penyakit, golongan darah, makanan pokok, lauk pauk, buah dan sayuran yang telah ditentukan oleh ahli gizi pada puskesmas Sawah Lebar Baru Kota Bengkulu. Data-data tersebut akan digunakan dalam Sistem Pakar dengan mengimplementasikan metode Backward Chaining. Pasien berkonsultasi dengan menjawab pertanyaan yang telah disediakan dalam sistem untuk mengetahui menu makanan yang tepat berdasarkan hasil konsultasinya.

\section{Analisis Permasalahan}

Kurangnya pengetahuan tentang menu makanan yang sesuai pada penderita penyakit dan golongan darah tertentu dapat menimbulkan efek yang buruk dalam tubuh pasien.

\section{Analisis Kebutuhan Sistem}

Pada tahap ini dilakukan analisis kebutuhan data, analisis input dan output sistem, analisis fungsi sistem dan analisis batasan sistem.

Adapun kebutuhan data pada Sistem Pakar untuk menentukan menu makanan berdasarkan penyakit dan golongan darah yang diusulkan adalah sebagai berikut:

\section{a. Data Penyakit}

Data penyakit disimpan di dalam sistem untuk proses penelusuran dengan Backward Chaining. Berikut ini adalah data penyakit yang dibutuhkan dalam Sistem Pakar penentuan menu makanan berdasarkan penyakit dan golongan darah:

\begin{tabular}{|c|l|} 
Tabel 1. Penyakit \\
\begin{tabular}{|c|l|}
\hline Kode & Nama Penyakit \\
\hline P01 & Penyakit Jantung \\
\hline P02 & Penyakit Kolesterol \\
\hline P03 & Penyakit Diabetes \\
\hline P04 & Penyakit Asam Urat \\
\hline
\end{tabular}
\end{tabular}

\section{b. Data Golongan Darah}

Berikut ini adalah data golongan darah yang dibutuhkan dalam Sistem Pakar penentuan menu makanan berdasarkan penyakit dan golongan darah:

Tabel 2. Golongan Darah

\begin{tabular}{|c|l|}
\hline Kode & Nama Golongan Darah \\
\hline $\mathrm{A}$ & Golongan Darah A \\
\hline $\mathrm{AB}$ & Golongan Darah $\mathrm{AB}$ \\
\hline $\mathrm{B}$ & Golongan Darah B \\
\hline $\mathrm{O}$ & Golongan Darah O \\
\hline
\end{tabular}


Jurnal Pseudocode, Volume V Nomor 1, Februari 2018, ISSN 2355-5920 www.ejournal.unib.ac.id/index.php/pseudocode

\section{c. Data Makanan Pokok}

Berikut adaalah data makanan pokok untuk Sistem Pakar pemilihan menu makanan berdasarkan penyakit dan golongan darah:

\begin{tabular}{|l|l|}
\multicolumn{2}{|c}{ Tabel 3. Makanan Pokok } \\
\hline Kode & Nama Makanan Pokok \\
\hline MP01 & Jagung Rebus \\
\hline MP02 & Kentang Rebus \\
\hline MP03 & Ketan Putih \\
\hline MP04 & Nasi Putih \\
\hline MP05 & Nasi Putih Kentucky \\
\hline MP06 & Nasi Tim \\
\hline MP07 & Nasi Uduk \\
\hline MP08 & Bihun Goreng \\
\hline MP09 & Kentang Goreng \\
\hline MP10 & Mie Goreng \\
\hline MP11 & Nasi Goreng \\
\hline
\end{tabular}

\section{d. Data Lauk Pauk}

Berikut adalah data lauk pauk untuk Sistem Pakar pemilihan menu makanan berdasarkan penyakit dan golongan darah:

\begin{tabular}{|l|l|}
\multicolumn{2}{l}{ Tabel 4. Data Lauk Pauk } \\
\hline Kode & Lauk Pauk \\
\hline LP01 & Ayam Bakar \\
\hline LP02 & Ayam Panggang \\
\hline LP03 & Daging Panggang \\
\hline LP04 & Ikan Mas Pepes \\
\hline LP05 & Telur Asin Rebus \\
\hline LP06 & Telur Ayam Rebus \\
\hline LP07 & Udang Rebus \\
\hline LP08 & Ayam Pop \\
\hline LP09 & Empal Daging \\
\hline LP10 & Ikan Bandeng Goreng \\
\hline LP11 & Ikan Bawal Goreng \\
\hline LP12 & Ikan Kembung Goreng \\
\hline LP13 & Ikan Lele Goreng \\
\hline LP14 & Ikan Patin Goreng \\
\hline LP15 & Ikan Tenggiri Goreng \\
\hline LP16 & Ikan Teri Goreng \\
\hline LP17 & Ikan Tuna Goreng \\
\hline LP18 & Kerang Rebus \\
\hline LP19 & Udang Goreng Besar \\
\hline LP20 & Telur Mata Sapi \\
\hline LP21 & Abon Sapi \\
\hline LP22 & Ayam Goreng Kecap \\
\hline LP23 & Dendeng Balado \\
\hline LP24 & Gulai Ayam \\
\hline & \\
\hline
\end{tabular}

\begin{tabular}{|l|l|}
\hline LP25 & Gulai Kepala Ikan Kakap \\
\hline LP26 & Gulai Limpa \\
\hline LP27 & Gulai Tunjang \\
\hline LP28 & Ikan Teri \\
\hline LP29 & Semur Ayam \\
\hline LP30 & Sop Sapi \\
\hline LP31 & Telur dadar \\
\hline LP32 & Sambal Goreng Tempe \\
\hline LP33 & Tahu Bacem \\
\hline LP34 & Tempe Bacem \\
\hline LP35 & Tempe Goreng \\
\hline LP36 & Keripik Tempe \\
\hline LP37 & Perkedel Jagung \\
\hline LP38 & Perkedel Kentang \\
\hline LP39 & Tahu Goreng \\
\hline LP40 & Sambal Goreng Ati \\
\hline LP41 & Sambal Goreng Tempe teri \\
\hline
\end{tabular}

\section{e. Data Sayuran}

Berikut adalah data sayuran untuk Sistem Pakar pemilihan menu makanan berdasarkan penyakit dan golongan darah:

\begin{tabular}{|l|l|}
\multicolumn{2}{|c|}{ Tabel 5. Data Sayuran } \\
\hline Kode & \multicolumn{1}{c|}{ Sayuran } \\
\hline SYR01 & Acar Kuning \\
\hline SYR02 & Bening Bayam \\
\hline SYR03 & Cah Labu Siam \\
\hline SYR04 & Sayur Asam \\
\hline SYR05 & Sop Ayam Kombinasi \\
\hline SYR06 & Sop Bayam \\
\hline SYR07 & Sop Kimlo \\
\hline SYR08 & Sop Mutiara Jagung \\
\hline SYR09 & sop Oyong Misoa \\
\hline SYR10 & Sop Telur Putuh \\
\hline SYR11 & Sayur Lodeh \\
\hline SYR12 & Cah Jagung Putren \\
\hline SYR13 & Cah kacang Panjang \\
\hline SYR14 & Sop Oyong Telur Puyuh \\
\hline SYR15 & Setup Kentang Buncis \\
\hline SYR16 & Tumis Buncis \\
\hline SYR17 & Tumis Daun Singkong \\
\hline SYR18 & Tumis Kc. Panjang Jagung \\
\hline
\end{tabular}

\section{f. Data Buah}

Berikut adalah data buah untuk Sistem Pakar pemilihan menu makanan berdasarkan penyakit dan golongan darah: 
Jurnal Pseudocode, Volume V Nomor 1, Februari 2018, ISSN 2355-5920 www.ejournal.unib.ac.id/index.php/pseudocode

\begin{tabular}{|l|l|}
\multicolumn{2}{l}{ Tabel 6. Data Buah } \\
\hline Kode & Nama Buah \\
\hline BH01 & Apel \\
\hline BH02 & Apel Merah \\
\hline BH03 & Belimbing \\
\hline BH04 & Duku \\
\hline BH05 & Jambu Air \\
\hline BH06 & Jambu Biji \\
\hline BH07 & Jeruk Medan \\
\hline BH08 & Jeruk Pontianak \\
\hline BH09 & Jeruk Sunkist \\
\hline BH10 & Mangga Manalagi \\
\hline BH11 & Nanas \\
\hline BH12 & Pepaya \\
\hline BH13 & Pir \\
\hline BH14 & Pisang Rebus \\
\hline BH15 & Salak \\
\hline BH16 & Semangka \\
\hline
\end{tabular}

g. Data Rule

Berikut adalah rule untuk Sistem Pakar pemilihan menu makanan berdasarkan penyakit dan golongan darah:

Tabel 7. Data Rule

\begin{tabular}{|c|l|}
\hline Kode & \multicolumn{1}{|c|}{ Kondisi dan Aksi } \\
\hline R01 & Jika GOLA dan P01 (Jantung) Maka \\
& MP04,MP07,LP01, LP04,LP06, SYR02, \\
& SYR04, SYR16,BH12,BH14,BH16 Solusi : \\
& PAGI (MP07,LP06,SYR02,BH12) \\
& SIANG(MP04,LP04,SYR04,BH14) \\
& SORE(MP04,LP06,SYR16,BH16) \\
\hline R02 & Jika GOLA dan P02 (Kolesterol) maka \\
& MP04,MP09,LP04,LP10,LP13,SYR02,SYR0 \\
& 4,SYR18,BH12, BH14,BH16 \\
& Solusi : PAGI (MP09,LP10,SYR02,BH12) \\
& SIANG(MP04,LP04,SYR04,BH14) \\
& SORE(MP04,LP13,SYR18,BH16) \\
\hline R03 & Jika GOLA dan P03 (Diabetes) maka \\
& MP01,MP04,MP09,LP01,LP07,LP20, \\
& SYR01, SYR02,SYR04,BH10,BH12,BH14 \\
& Solusi : PAGI (MP01,LP01,SYR01,BH10) \\
& SIANG(MP04,LP07,SYR02,BH12) \\
& SORE(MP09,LP020,SYR04,BH14) \\
\hline R04 & Jika GOLA dan P04 (Asam Urat) maka \\
& MP04,MP07,LP01,LP04,LP06,SYR02.SYR \\
& 06, SYR16,BH12,BH14,BH16 \\
& Solusi : PAGI (MP07,LP06,SYR02,BH12) \\
& SIANG(MP04,LP04,SYR06,BH14) \\
& SORE(MP04,LP06,SYR16,BH16) \\
\hline R05 & Jika GOLB dan P01 (Jantung) maka \\
& MP06,MP04,LP10,LP20,LP22,SYR06,SYR1 \\
& 1, SYR15,BH04,BH12,BH14 \\
& Solusi : PAGI (MP06,LP10,SYR06,BH04) \\
& SIANG(MP04,LP20,SYR11,BH12) \\
& SORE(MP04,LP22,SYR15,BH14) \\
& Jika GOLB dan P02 (Kolesterol) maka \\
& MP07,MP04,LP04,LP10,LP13,SYR02,SYR0 \\
& 4, SYR18,BH12,BH14,BH16 \\
& Solusi : PAGI (MP07,LP10,SYR02,BH12) \\
& SIANG(MP04,LP04,SYR04,BH14) \\
& SORE(MP04,LP13,SYR18,BH16) \\
\hline & \\
\hline
\end{tabular}

\begin{tabular}{|c|c|}
\hline R07 & $\begin{array}{l}\text { Jika GOLB dan P03 (Diabetes) maka } \\
\text { MP01,MP04,MP09,LP01,LP07,LP20,SYR01 } \\
\text {, SYR02,SYR04,BH02,BH10,BH12 } \\
\text { Solusi : PAGI (MP01,LP01,SYR01,BH02) } \\
\text { SIANG(MP04,LP07,SYR02,BH10) } \\
\text { SORE(MP09,LP020,SYR04,BH12) }\end{array}$ \\
\hline R08 & $\begin{array}{l}\text { Jika GOLB dan P04 (Asam Urat) maka } \\
\text { MP04,MP07,LP01,LP04,LP06,SYR02.SYR0 } \\
\text { 6, SYR16,BH10,BH12,BH14 } \\
\text { Solusi : PAGI (MP07,LP06,SYR02,BH10) } \\
\text { SIANG(MP04,LP04,SYR06,BH12) } \\
\text { SORE(MP04,LP06,SYR16,BH14) }\end{array}$ \\
\hline R09 & $\begin{array}{l}\text { Jika GOLO dan P01 (Jantung) maka } \\
\text { MP04,MP07,LP01,LP04,LP06,SYR02,SYR0 } \\
\text { 4, SYR16,BH12,BH14,BH16 } \\
\text { Solusi : PAG(MP07,LP06,SYR02,BH12) } \\
\text { SIANG( P04,LP04,SYR04,BH14) } \\
\text { SORE(MP04,LP06,SYR16,BH16) }\end{array}$ \\
\hline R10 & $\begin{array}{l}\text { Jika GOLO dan P02 (Kolesterol) maka } \\
\text { MP04,MP09,LP04,LP10,LP13,SYR02,SYR0 } \\
\text { 4, SYR18,BH12,BH14,BH16 } \\
\text { Solusi : PAGI (MP09,LP10,SYR02,BH12) } \\
\text { SIANG(MP04,LP04,SYR04,BH14) } \\
\text { SORE(MP04,LP13,SYR18,BH16) }\end{array}$ \\
\hline R11 & $\begin{array}{l}\text { Jika GOLO dan P03 (Diabetes) maka } \\
\text { MP01,MP04,MP09,LP01,LP07,LP20,SYR01 } \\
\text {, SYR02,SYR04,BH10,BH12,BH14 } \\
\text { Solusi : PAGI (MP01,LP01,SYR01,BH10) } \\
\text { SIANG(MP04,LP07,SYR02,BH12) } \\
\text { SORE(MP09,LP020,SYR04,BH14) }\end{array}$ \\
\hline R12 & $\begin{array}{l}\text { Jika GOLO dan P04 (Asam Urat) maka } \\
\text { MP04,MP07,LP01,LP04,LP06,SYR02.SYR0 } \\
\text { 6, SYR16,BH12,BH14,BH16 } \\
\text { Solusi : PAGI (MP07,LP06,SYR02,BH12) } \\
\text { SIANG(MP04,LP04,SYR06,BH14) } \\
\text { SORE(MP04,LP06,SYR16,BH16) }\end{array}$ \\
\hline R13 & $\begin{array}{l}\text { Jika GOLAB dan P01 (Jantung) maka } \\
\text { MP04,MP07,LP01,LP04,LP06,SYR02,SYR0 } \\
\text { 4, SYR16,BH12,BH14,BH16 } \\
\text { Solusi : PAGI (MP07,LP06,SYR02,BH12) } \\
\text { SIANG(MP04,LP04,SYR04,BH14) } \\
\text { SORE(MP04,LP06,SYR16,BH16) }\end{array}$ \\
\hline R14 & $\begin{array}{l}\text { Jika GOLAB dan P02 (Kolesterol) maka } \\
\text { MP04,MP09,LP04,LP10,LP13,SYR02,SYR0 } \\
\text { 4, SYR18,BH12,BH14,BH16 } \\
\text { Solusi : PAGI (MP09,LP10,SYR02,BH12) } \\
\text { SIANG(MP04,LP04,SYR04,BH14) } \\
\text { SORE(MP04,LP13,SYR18,BH16) }\end{array}$ \\
\hline R15 & $\begin{array}{l}\text { Jika GOLAB dan P03 (Diabetes) maka } \\
\text { MP01,MP04,MP09,LP01,LP07,LP20,SYR01 } \\
\text {, SYR02,SYR04,BH10,BH12,BH14 } \\
\text { Solusi : PAGI (MP01,LP01,SYR01,BH10) } \\
\text { SIANG(MP04,LP07,SYR02,BH12) }\end{array}$ \\
\hline R16 & $\begin{array}{l}\text { Jika GOLAB dan P04 (Asam Urat) maka } \\
\text { MP04,MP07,LP01,LP04,LP06,SYR02.SYR0 } \\
\text { 6, SYR16,BH12,BH14,BH16 } \\
\text { Solusi:PAGI(MP07,LP06,SYR02,BH12) } \\
\text { SIANG(MP04,LP04,SYR06,BH14) } \\
\text { SORE(MP04,LP06,SYR16,BH16) }\end{array}$ \\
\hline
\end{tabular}




\section{h. Data Solusi}

Data solusi menyimpan daftar menu makanan yang dianjurkan berdasarkan penyakit dan golongan darah pasien. Menu makanan pada daftar solusi diambil dari data makanan pokok, data lauk pauk, data buah dan data sayuran kemudian dikelompokkan lagi berdasarkan waktu konsumsi yaitu pagi, siang dan sore. Adapun data solusi terlihat pada tabel berikut:

\begin{tabular}{|c|c|c|c|}
\hline \multirow[t]{2}{*}{ Kode } & \multicolumn{3}{|c|}{ Menu Makanan } \\
\hline & Pagi & Siang & Sore \\
\hline S01 & $\begin{array}{l}\text { Nasi Uduk, } \\
\text { Telur Ayam } \\
\text { Rebus, } \\
\text { Bening } \\
\text { Bayam, } \\
\text { Pepaya }\end{array}$ & $\begin{array}{l}\text { Nasi Putih, } \\
\text { Ikan Mas } \\
\text { Pepes, } \\
\text { Sayur } \\
\text { Asam, } \\
\text { Pisang } \\
\text { Rebus }\end{array}$ & $\begin{array}{l}\text { Nasi Putih, } \\
\text { Telur Ayam } \\
\text { Rebus, Tumis } \\
\text { Buncis, } \\
\text { Semangka }\end{array}$ \\
\hline $\mathrm{S} 02$ & $\begin{array}{l}\text { Kentang } \\
\text { Goreng, } \\
\text { Ikan } \\
\text { Bandeng } \\
\text { Goreng, } \\
\text { Bening } \\
\text { Bayam, } \\
\text { Pepaya } \\
\end{array}$ & $\begin{array}{l}\text { Nasi Putih, } \\
\text { Ikan Mas } \\
\text { Pepes, } \\
\text { Sayur } \\
\text { Asam, } \\
\text { Pisang } \\
\text { Rebus }\end{array}$ & $\begin{array}{l}\text { Nasi Putih, } \\
\text { Ikan Lele } \\
\text { Goreng, } \\
\text { Tumis Kc. } \\
\text { Panjang } \\
\text { Jagung, } \\
\text { Semangka }\end{array}$ \\
\hline S03 & $\begin{array}{l}\text { Jagung } \\
\text { Rebus, } \\
\text { Ayam } \\
\text { Bakar, Acar } \\
\text { Kuning, } \\
\text { Mangga } \\
\text { Manalagi }\end{array}$ & $\begin{array}{l}\text { Nasi Putih, } \\
\text { Udang } \\
\text { Rebus, } \\
\text { Bening } \\
\text { Bayam, } \\
\text { Pepaya }\end{array}$ & $\begin{array}{l}\text { Kentang } \\
\text { Goreng, } \\
\text { Ayam } \\
\text { Panggang, } \\
\text { Sayur Asam, } \\
\text { Pisang Rebus }\end{array}$ \\
\hline S04 & $\begin{array}{l}\text { Nasi Uduk, } \\
\text { Telur Ayam } \\
\text { Rebus, } \\
\text { Bening } \\
\text { Bayam, } \\
\text { Pepaya } \\
\end{array}$ & $\begin{array}{l}\text { Nasi Putih, } \\
\text { Ikan Mas } \\
\text { Pepes, Sop } \\
\text { Bayam, } \\
\text { Pisang } \\
\text { Rebus } \\
\end{array}$ & $\begin{array}{l}\text { Nasi Putih, } \\
\text { Telur Ayam } \\
\text { Rebus, Tumis } \\
\text { Buncis, } \\
\text { Semangka }\end{array}$ \\
\hline S05 & $\begin{array}{l}\text { Nasi Tim, } \\
\text { Ikan } \\
\text { Bandeng } \\
\text { Goreng, Sop } \\
\text { Bayam, } \\
\text { Duku }\end{array}$ & $\begin{array}{l}\text { Nasi Putih, } \\
\text { Telur Mata } \\
\text { Sapi, Sayur } \\
\text { Lodeh, } \\
\text { Pepaya }\end{array}$ & $\begin{array}{l}\text { Nasi Putih, } \\
\text { Ayam Goreng } \\
\text { Kecap, Setup } \\
\text { Kentang } \\
\text { Buncis, } \\
\text { Pisang Rebus }\end{array}$ \\
\hline S06 & $\begin{array}{l}\text { Nasi Uduk, } \\
\text { Ikan } \\
\text { Bandeng } \\
\text { Goreng, } \\
\text { Bening } \\
\text { Bayam, } \\
\text { Pepaya } \\
\end{array}$ & $\begin{array}{l}\text { Nasi Putih, } \\
\text { Ikan Mas } \\
\text { Pepes, } \\
\text { Sayur } \\
\text { Asam, } \\
\text { Pisang } \\
\text { Rebus }\end{array}$ & $\begin{array}{l}\text { Nasi Putih, } \\
\text { Ikan Lele } \\
\text { Goreng, } \\
\text { Tumis Kc. } \\
\text { Panjang } \\
\text { Jagung, } \\
\text { Semangka }\end{array}$ \\
\hline S08 & $\begin{array}{l}\text { Nasi Uduk, } \\
\text { Telur Ayam } \\
\text { Rebus, } \\
\text { Bening } \\
\end{array}$ & $\begin{array}{l}\text { Nasi Putih, } \\
\text { Ikan Mas } \\
\text { Pepes, Sop } \\
\text { Bayam, }\end{array}$ & $\begin{array}{l}\text { Nasi Putih, } \\
\text { Telur Ayam } \\
\text { Rebus, Tumis } \\
\text { Buncis, }\end{array}$ \\
\hline
\end{tabular}

\begin{tabular}{|c|c|c|c|}
\hline & $\begin{array}{l}\text { Bayam, } \\
\text { Mangga } \\
\text { Manalagi }\end{array}$ & Pepaya & Pisang Rebus \\
\hline S09 & $\begin{array}{l}\text { Nasi Uduk, } \\
\text { Telur ayam } \\
\text { Rebus, } \\
\text { Bening } \\
\text { Bayam, } \\
\text { Pepaya }\end{array}$ & $\begin{array}{l}\text { Nasi Putih, } \\
\text { Ikan Mas } \\
\text { Pepes, } \\
\text { Sayur } \\
\text { Asam, } \\
\text { Pisang } \\
\text { Rebus }\end{array}$ & $\begin{array}{l}\text { Nasi Putih, } \\
\text { Telur Rebus, } \\
\text { Tumis Buncis, } \\
\text { Semangka }\end{array}$ \\
\hline $\mathrm{S} 10$ & $\begin{array}{l}\text { Kentang } \\
\text { Goreng,Ikan } \\
\text { Bandeng } \\
\text { Goreng, } \\
\text { Bening } \\
\text { Bayam, } \\
\text { Pepaya }\end{array}$ & $\begin{array}{l}\text { Nasi Putih, } \\
\text { Ikan Mas } \\
\text { Pepes, } \\
\text { Sayur } \\
\text { Asam, } \\
\text { Pisang } \\
\text { Rebus }\end{array}$ & $\begin{array}{l}\text { Nasi Putih, } \\
\text { Ikan Lele } \\
\text { Goreng, } \\
\text { Tumis Kc. } \\
\text { Panjang } \\
\text { Jagung, } \\
\text { Semangka }\end{array}$ \\
\hline S11 & $\begin{array}{l}\text { Jagung } \\
\text { Rebus, } \\
\text { Ayam } \\
\text { Bakar, Acar } \\
\text { Kuning, } \\
\text { Mangga } \\
\text { Manalagi }\end{array}$ & $\begin{array}{l}\text { Nasi Putih, } \\
\text { Udang } \\
\text { Rebus, } \\
\text { Bening } \\
\text { Bayam, } \\
\text { Pepaya }\end{array}$ & $\begin{array}{l}\text { Kentang } \\
\text { Goreng, Telur } \\
\text { Mata Sapi, } \\
\text { Sayur Asam, } \\
\text { Pisang Rebus }\end{array}$ \\
\hline $\mathrm{S} 12$ & $\begin{array}{l}\text { Nasi Uduk, } \\
\text { Telur Ayam } \\
\text { Rebus, } \\
\text { Bening } \\
\text { Bayam, } \\
\text { Pepaya }\end{array}$ & $\begin{array}{l}\text { Nasi Putih, } \\
\text { Ikan Mas } \\
\text { Pepes, Sop } \\
\text { Bayam, } \\
\text { Pisang } \\
\text { Rebus }\end{array}$ & $\begin{array}{l}\text { Nasi Putih, } \\
\text { Telur Ayam } \\
\text { Rebus, Tumis } \\
\text { Buncis, } \\
\text { Semangka }\end{array}$ \\
\hline S13 & $\begin{array}{l}\text { Nasi Uduk, } \\
\text { Telur Ayam } \\
\text { Rebus, } \\
\text { Bening } \\
\text { Bayam, } \\
\text { Pepaya }\end{array}$ & $\begin{array}{l}\text { Nasi Putih, } \\
\text { Ikan Mas } \\
\text { Pepes, } \\
\text { Sayur } \\
\text { Asam, } \\
\text { Pisang } \\
\text { Rebus }\end{array}$ & $\begin{array}{l}\text { Nasi Putih, } \\
\text { Telur Ayam } \\
\text { Rebus, Tumis } \\
\text { Buncis, } \\
\text { Semangka }\end{array}$ \\
\hline S14 & $\begin{array}{l}\text { Kentang } \\
\text { Goreng, } \\
\text { Ikan } \\
\text { Bandeng } \\
\text { Goreng, } \\
\text { Bening } \\
\text { Bayam, } \\
\text { Pepaya }\end{array}$ & $\begin{array}{l}\text { Nasi Putih, } \\
\text { Ikan Mas } \\
\text { Pepes, } \\
\text { Sayur } \\
\text { Asam, } \\
\text { Pisang } \\
\text { Rebus }\end{array}$ & $\begin{array}{l}\text { Nasi Putih, } \\
\text { Ikan Lele } \\
\text { Goreng, } \\
\text { Tumis Kc. } \\
\text { Panjang } \\
\text { Jagung, } \\
\text { Semangka }\end{array}$ \\
\hline S15 & $\begin{array}{l}\text { Jagung } \\
\text { Rebus, } \\
\text { Ayam } \\
\text { Bakar, Acar } \\
\text { Kuning, } \\
\text { Mangga } \\
\text { Manalagi }\end{array}$ & $\begin{array}{l}\text { Nasi Putih, } \\
\text { Udang } \\
\text { Rebus, } \\
\text { Bening } \\
\text { Bayam, } \\
\text { Pepaya }\end{array}$ & $\begin{array}{l}\text { Kentang } \\
\text { Goreng, Telur } \\
\text { Mata Sapi, } \\
\text { Sayur Asam, } \\
\text { Pisang Rebus }\end{array}$ \\
\hline S16 & $\begin{array}{l}\text { Nasi Uduk, } \\
\text { Telur Ayam } \\
\text { Rebus, } \\
\text { Bening } \\
\text { Bayam, } \\
\text { Pepaya }\end{array}$ & $\begin{array}{l}\text { Nasi Putih, } \\
\text { Ikan Mas } \\
\text { Pepes, Sop } \\
\text { Bayam, } \\
\text { Pisang } \\
\text { Rebus }\end{array}$ & $\begin{array}{l}\text { Nasi Putih, } \\
\text { Telur Ayam } \\
\text { Rebus, Tumis } \\
\text { Buncis, } \\
\text { Semangka }\end{array}$ \\
\hline
\end{tabular}

\section{Analisa Perancangan Sistem}

Pada tahapan ini dilakukan desain arsitektur Sistem Pakar yang terdiri dari pembuatan basis 
pengetahuan (Knowledge Base), mesin inferensi, perancangan antarmuka sistem.

Flowchart. Perancangan basis data dan

\begin{tabular}{|l|}
\hline Knowledge \\
Berisi himpunan-himpunan: \\
1. Penyakit \\
2. Golongan Darah \\
3. Makanan Pokok \\
4. Lauk Pauk \\
5. Sayuran \\
6. Buah \\
7. Solusi \\
\hline
\end{tabular}

\section{Database}

Menyimpan fakta-fakta

1. Tabel Penyakit

2. Tabel Golongan Darah

3. Tabel Makanan Pokok

4. Tabel Lauk Pauk

5. Tabel Sayuran

6. Tabel Buah

7. Tabel Solusi

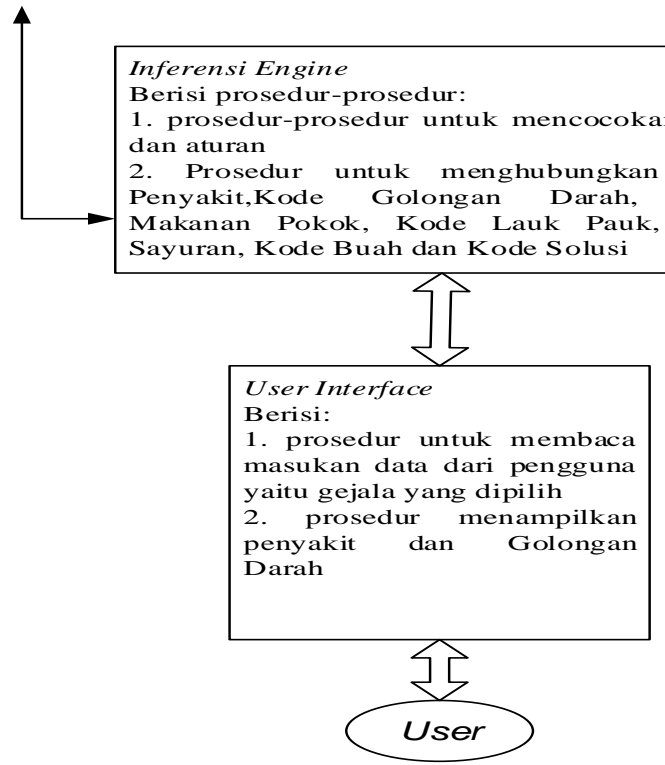

Gambar 1. Desain Arsitektur Sistem Pakar

\section{Mesin Inferensi}

Mesin inferensi yang digunakan dalam sistem ini dibuat dengan metode Backward Chaining. Adapun tujuannya adalah untuk menentukan menu makanan berdasarkan penyakit dan golongan darah yang dipilih oleh user.

\section{E. Database}

Dalam perancangan sistem membutuhkan database yang berfungsi sebagai penyimpanan data yang akan diproses dalam Sistem Pakar.

\section{Tabel User}

Tabel user menyimpan username dan password yang digunakan oleh admin atau pakar dalam mengelola data dalam Sistem Pakar.

Tabel 9. User

\begin{tabular}{|c|c|c|c|l|}
\hline No & Field & Tipe & Panjang & Keterangan \\
\hline 1 & Username & Text & 20 & $\begin{array}{l}\text { Nama } \\
\text { Pengguna }\end{array}$ \\
\hline 2 & Password & Text & 20 & $\begin{array}{l}\text { Password } \\
\text { Pengguna }\end{array}$ \\
\hline
\end{tabular}

\begin{tabular}{|l|l|}
\hline Total & 40 Bytes \\
\hline
\end{tabular}

\section{Tabel Penyakit}

Tabel penyakit digunakan untuk menyimpan data penyakit yang ditentukan oleh pakar.

\begin{tabular}{|c|c|c|c|c|}
\hline No & Field & Tipe & Panjang & $\begin{array}{c}\text { Keteran } \\
\text { gan }\end{array}$ \\
\hline 1 & Kd_penyakit & Text & 3 & $\begin{array}{l}\text { Kode } \\
\text { Penyakit }\end{array}$ \\
\hline 2 & Nm_penyakit & Text & 40 & $\begin{array}{l}\text { Nama } \\
\text { Penyakit }\end{array}$ \\
\hline \multicolumn{7}{|c|}{ Total } & 43 bytes & \\
\hline
\end{tabular}

\section{Tabel Golongan Darah}

Tabel golongan darah digunakan untuk menyimpan data golongan darah.

Tabel 11. Golongan Darah

\begin{tabular}{|c|c|c|c|c|}
\hline No & Field & Tipe & Panjang & Keterangan \\
\hline 1 & Kd_gol_darah & Text & 2 & Kode Gol. Darah \\
\hline 2 & Nm_gol_darah & Text & 30 & Nama Gol. Dara \\
\hline \multicolumn{3}{|c|}{ Total } & \multicolumn{2}{c|}{32 Bytes } \\
\hline
\end{tabular}

4. Tabel Solusi 
Jurnal Pseudocode, Volume V Nomor 1, Februari 2018, ISSN 2355-5920 www.ejournal.unib.ac.id/index.php/pseudocode

Tabel solusi digunakan untuk menyimpan data solusi yang akan digunakan dalam rule Sistem Pakar untuk menentukan menu makanan berdasarkan penyakit dan golongan darah.

\begin{tabular}{|c|c|c|c|c|}
\hline No & Field & Tipe & Panjang & Keterangan \\
\hline 1 & Kd_solusi & Text & 4 & Kode Solusi \\
\hline 2 & Nm_solusi & Text & 30 & Nama Solusi \\
\hline \multicolumn{3}{|c|}{ Total } & 34 Bytes & \\
\hline
\end{tabular}

\section{Tabel Rule}

Tabel rule atau aturan ini menyimpan data yang terkait aturan penelusuran Backward Chaining dalam Sistem Pakar ini.

Tabel 13. Rule

\begin{tabular}{|c|c|c|c|c|}
\hline No & Field & Tipe & Panjang & Keterangan \\
\hline 1 & Kd_rule & Text & 5 & Kode Rule \\
\hline 2 & Kd_penyakit & Text & 3 & Kode Penyakit \\
\hline 3 & Kd_gol_darah & Text & 2 & $\begin{array}{l}\text { Kode Golongan } \\
\text { Darah }\end{array}$ \\
\hline 4 & Kd_Solusi & Text & 4 & Kode Solusi \\
\hline \multicolumn{3}{|c|}{ Total } & \multicolumn{2}{|c|}{14 ytes } \\
\hline
\end{tabular}

6. Tabel Pasien

Tabel pasien menyimpan data pasien yang akan melakukan konsultasi melalui Sistem Pakar ini.

Tabel 14. Pasien

\begin{tabular}{|c|l|c|c|l|}
\hline No & Field & Tipe & Panjang & Keterangan \\
\hline 1 & Kd_pasien & Text & 5 & Kode Pasien \\
\hline 2 & Nama & Text & 30 & Nama Pasien \\
\hline 3 & Umur & Number & 3 & Umur Pasien \\
\hline 4 & Tinggi & Number & 4 & Tinggi Badan \\
\hline 5 & Berat & Number & 4 & Berat Badan \\
\hline 6 & Imt & Number & 4 & IMT \\
\hline 7 & Alamat & Text & 30 & Alamat Pasien \\
\hline \multicolumn{7}{|c|}{ Total } & 80 Bytes \\
\hline 7
\end{tabular}

7. Tabel Konsultasi

Tabel konsultasi berfungsi untuk menyimpan data konsultasi pasien.

\begin{tabular}{|c|c|c|c|l|}
\multicolumn{7}{|c|}{ Tabel 15. Konsultasi } \\
\hline No & Field & Tipe & Panjan & Keterangan \\
\hline 1 & Kd_konsultasi & Text & 5 & $\begin{array}{l}\text { Kode } \\
\text { Konsultasi }\end{array}$ \\
\hline 2 & Tgl_konsultasi & DateTime & 8 & $\begin{array}{l}\text { Tanggal } \\
\text { Konsultasi }\end{array}$ \\
\hline 3 & Kd_pasien & Text & 5 & Kode Pasien \\
\hline
\end{tabular}

\begin{tabular}{|l|l|l|l|l|}
\hline 4 & Kd_rule & Text & 5 & Kode Rule \\
\hline \multicolumn{3}{|c|}{ Total } & \multicolumn{2}{|c|}{23 Bytes } \\
\hline
\end{tabular}

\section{E. Desain Antarmuka (User Interface)}

Antarmuka (user interface) diperlukan untuk komunikasi pengguna dengan Sistem Pakar. Untuk itu diperlukan desain antarmuka yang mudah digunakan (user friendly).

\section{IMPLEMENTASI DAN PENGUJIAN}

\section{A. Implementasi Sistem}

Konsep perancangan desain Sistem Pakar untuk menentukan menu makanan berdasarkan penyakit dan golongan darah dirancang berdasarkan penyakit, golongan darah dan solusi yang merupakan menu makanan yang cocok untuk disajikan. Langkah awal yang dilakukan adalah memilih hak akses, apakah seorang pakar atau admin dan juga pengguna. Seorang pakar melakukan login terlebih dahulu dengan cara memasukkan username dan password. Setelah berhasil melakukan login, pakar akan memasukkan data-data yang dibutuhkan. 5.2 Desain Antarmuka (Interface)

User Interface yang digunakan dalam perancangan Sistem Pakar untuk menentukan menu makanan berdasarkan penyakit dan golongan darah adalah dalam bentuk form yang diuraikan dalam sub bab berikut ini.

1. Tampilan Awal

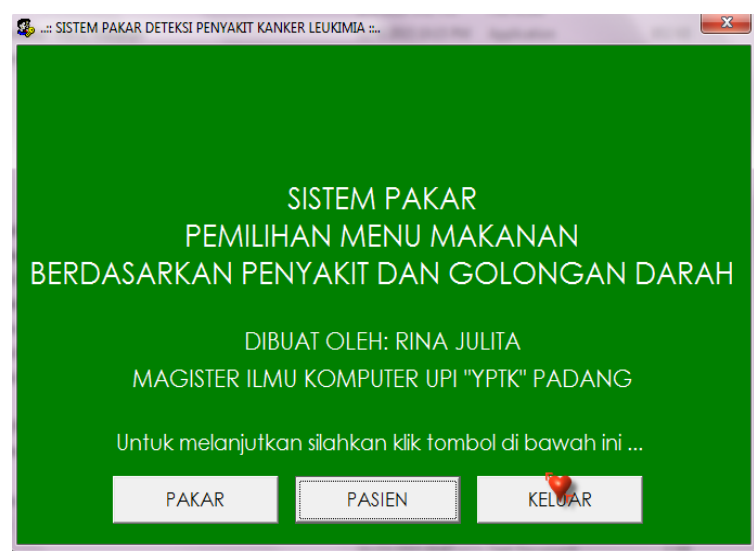

Gambar 3. Tampilan Awal 
Jurnal Pseudocode, Volume V Nomor 1, Februari 2018, ISSN 2355-5920

www.ejournal.unib.ac.id/index.php/pseudocode

2. Tampilan Halaman Login

Tampilan halaman login dapat dilihat pada

Gambar 4.

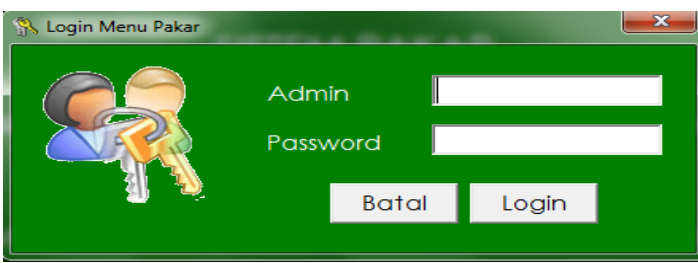

Gambar 4. Tampilan Halaman Login

3. Tampilan Halaman Utama (Home)

Menu utama dapat dilihat pada Gambar 5.

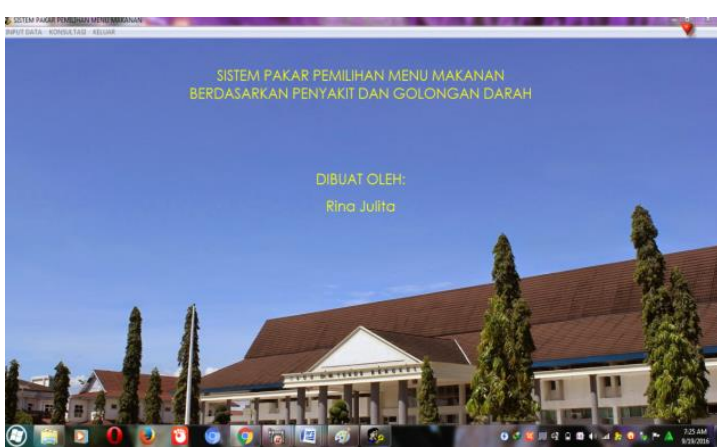

Gambar 5. Tampilan Halaman Utama (Home)

4. Tampilan Halaman Data Penyakit

Menu ini digunakan untuk menambah, memperbaiki dan menghapus data penyakit. Tampilan menu ini dapat dilihat pada Gambar 6.

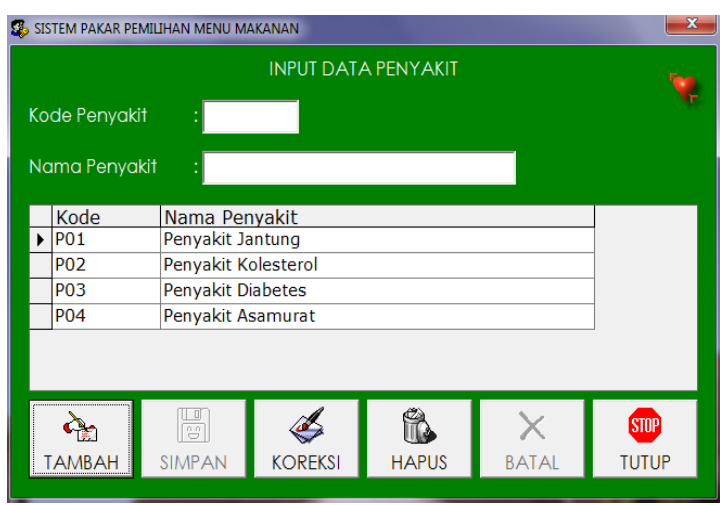

Gambar 6. Tampilan Menu Data Penyakit

5. Tampilan Halaman Data Golongan Darah

Tampilan menu ini dapat dilihat pada Gambar 7.

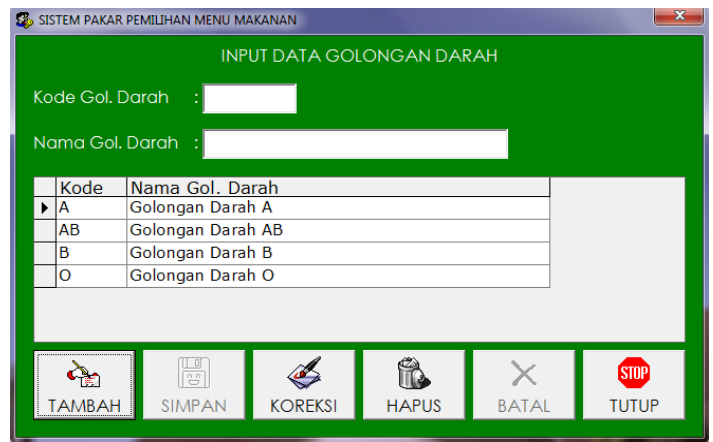

Gambar 7. Tampilan Halaman Data Golongan Darah

6. Tampilan Halaman Data Makanan Pokok Tampilan menu ini dapat dilihat pada Gambar 8 .

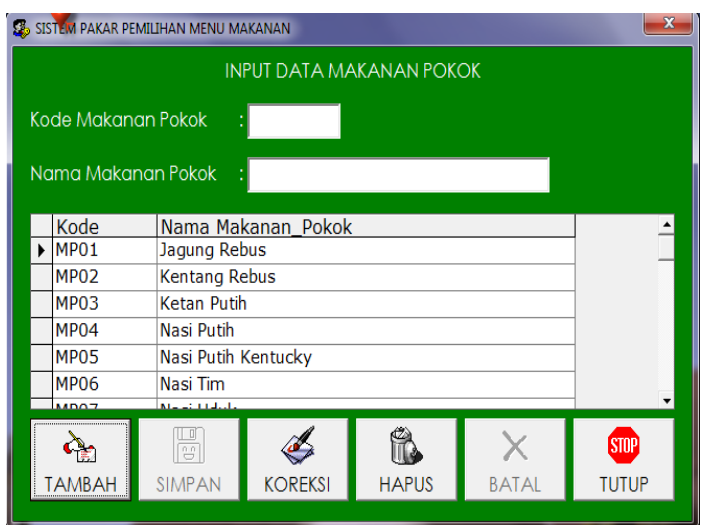

Gambar 8.

Tampilan Halaman Data

Makanan Pokok

7. Tampilan Halaman Data Lauk Pauk

Tampilan menu ini dapat dilihat pada Gambar 9.

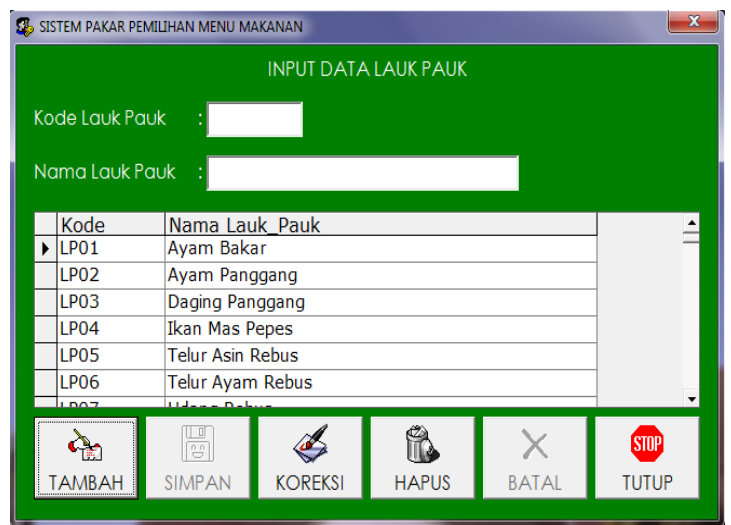

Gambar 9. Tampilan Halaman Data Lauk Pauk

8. Tampilan Halaman Data Sayuran

Tampilan menu ini dapat dilihat pada Gambar 10. 
Jurnal Pseudocode, Volume V Nomor 1, Februari 2018, ISSN 2355-5920 www.ejournal.unib.ac.id/index.php/pseudocode

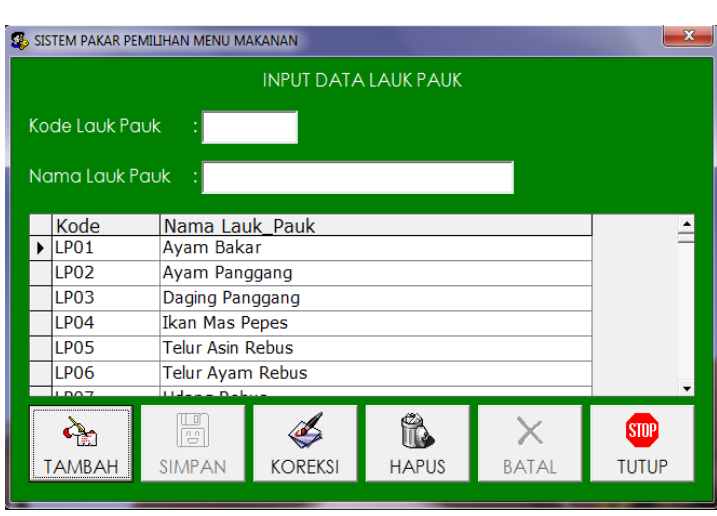

Gambar 10.

Tampilan Halaman Data Sayuran

9. Tampilan Halaman Data Buah-buahan

Tampilan menu dapat dilihat seperti Gambar 11.

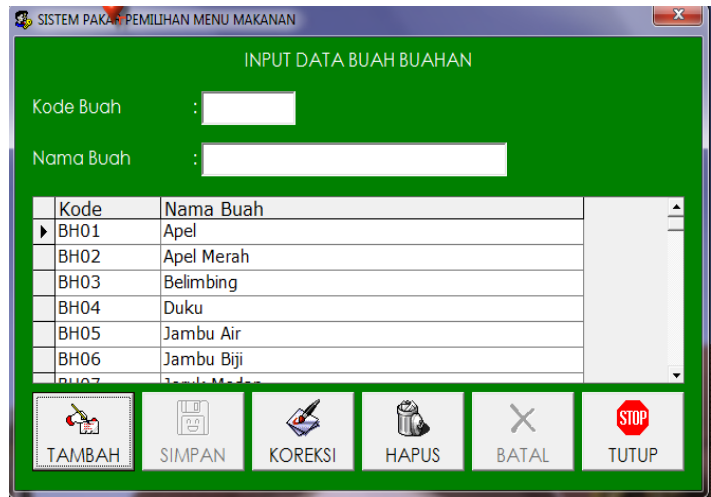

Gambar 11. Tampilan Halaman Data Buahbuahan

\section{Tampilan Halaman Data Rule}

Tampilan menu dapat dilihat seperti Gambar 12.

\section{Tampilan Halaman Data Konsultasi}

Tampilan menu dapat dilihat seperti Gambar 13

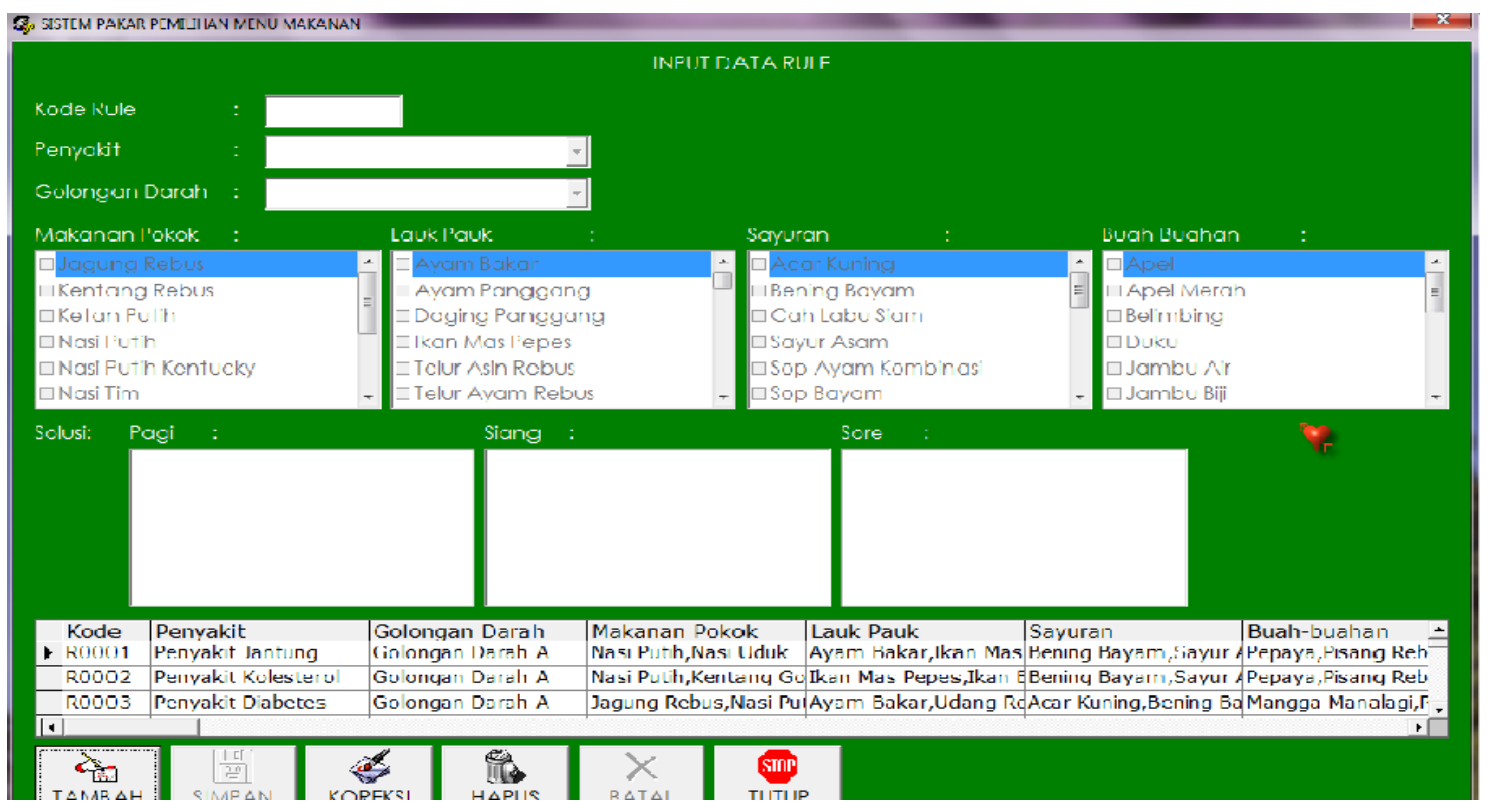

Gambar 12.Tampilan Halaman Data Rule

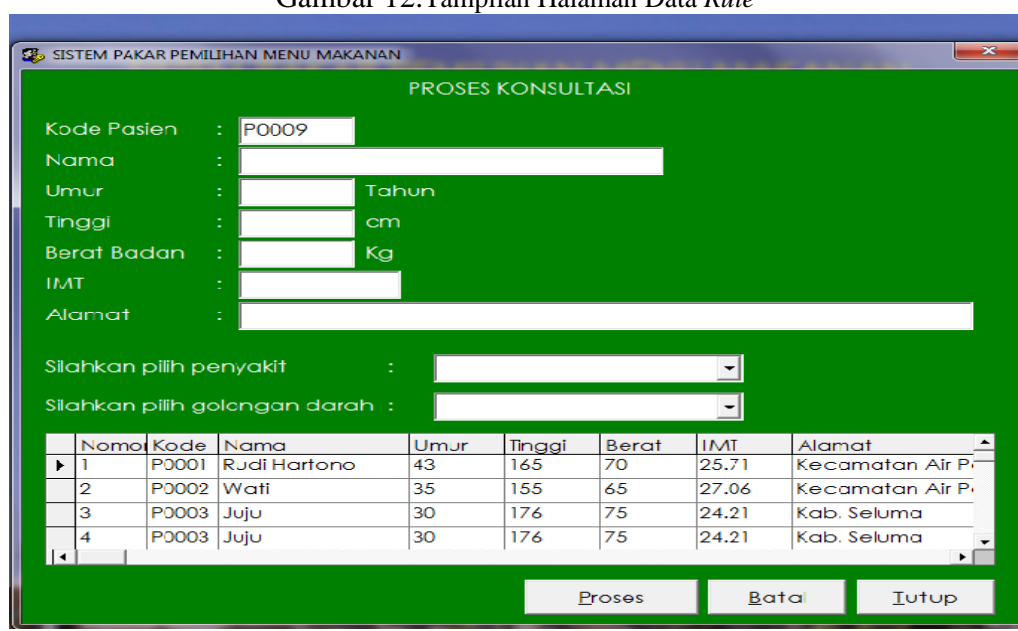

Gambar 13.Tampilan Halaman Data Konsultasi 


\section{Tampilan Halaman Hasil Konsultasi}

Tampilan menu dapat dilihat seperti Gambar 14.

\section{B. Pengujian Sistem}

Pengujian sistem dilakukan setelah sistem yang dibuat telah bisa dijalankan. Pengujian ini dilakukan untuk mengetahui sejauh mana kebenaran Sistem Pakar ini bekerja dengan melihat apakah hasil antara pengujian sistem dengan pengujian manual sama.

\section{KESIMPULAN DAN SARAN}

\section{A. Kesimpulan}

Berdasarkan dari keseluruhan antar sub bab yang sudah dibahas pada bab sebelumnya maka dapat disimpulkan sebagai berikut :

1. Rancangan Sistem Pakar dapat membantu menentukan menu makanan berdasarkan penyakit dan golongan darah.

2. Penerapan Metode Backward Chaining ini dapat menghasilkan pemilihan menu makanan berdasarkan penyakit dan golongan darah.

3. Sistem Pakar yang dibangun dapat membantu para analis dalam mementukan pemilihan menu makanan berdasarkan penyakit dan golongan darah.
4. Sistem Pakar pemilihan menu makanan ini dibuat dengan bahasa pemrograman Visual Basic 6, dapat digunakan sebagai alat bantu dalam menentukan pemilihan menu makanan berdasarkan penyakit dan golongan darah.

\section{B. Saran}

Untuk pengembangan dalam penelitian berikutnya makan diituliskan saran-saran sebagai berikut :

1. Sistem yang dibuat digunakan untuk menentukan menu makanan berdasarkan penyakit dan golongan darah dan bisa dikembangkan untuk lainnya.

2. Implementasi dan pengujian sistem untuk Metode Backward Chaining kita dapat menggunakan tools, Visual Basic 6.0 namun juga bisa dikembangkan dengan tools yang lain seperti Borland Delphi dan software lainnya.

\section{REFERENSI}

[1] Widiastuti W., Destiani D., dan Damiri D.J., (2012). “ Aplikasi Sistem Pakar Deteksi Dini Pada Penyakit Tuberkulosis". Garut.

[2] Sharma T., Tiwari N., dan Kelkar D.,(2013). "Study Of Difference Between Forward And Bacward Reasoning". International Journal Of Emerging Teknology And Advanced Engineering. ISSN 2250-2459, Vol.2.

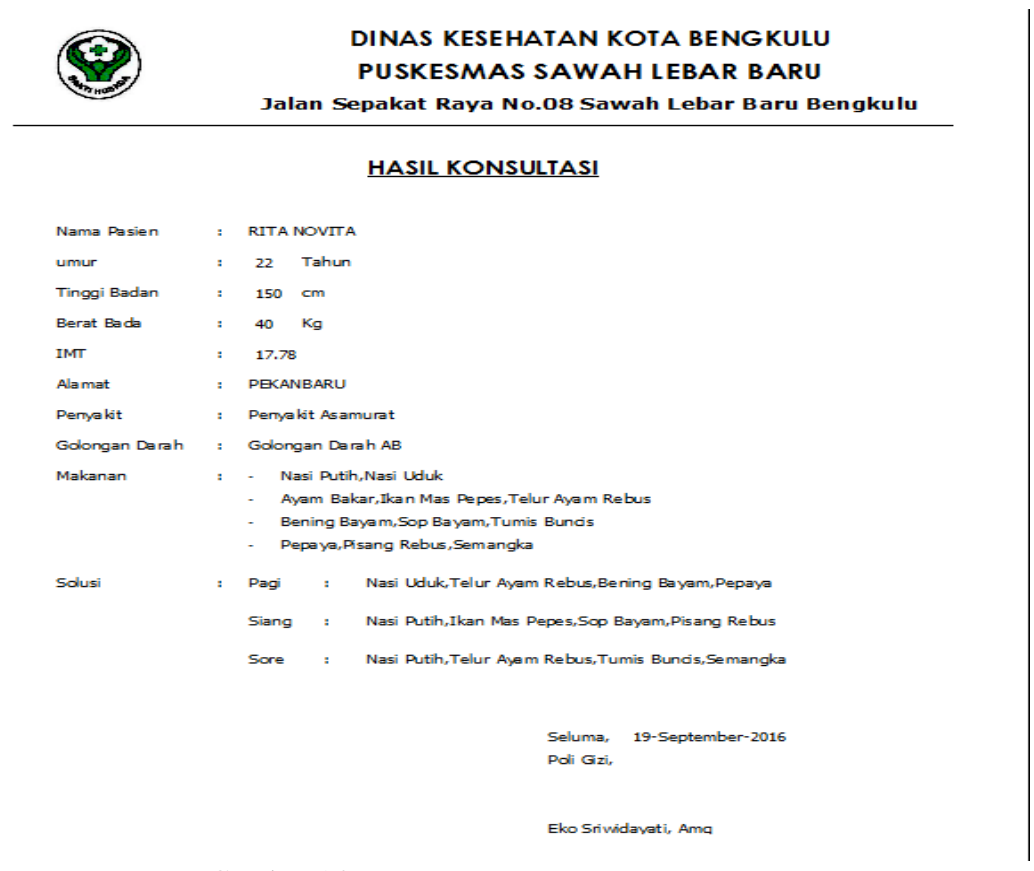

Gambar 14.Tampilan Halaman Hasil Konsultasi 
Jurnal Pseudocode, Volume V Nomor 1, Februari 2018, ISSN 2355-5920 www.ejournal.unib.ac.id/index.php/pseudocode 